\title{
The Multifaceted Role of Macrophages in Oncolytic Virotherapy
}

\author{
Laura Hofman ${ }^{1}\left(\mathbb{D}\right.$, Sean E. Lawler ${ }^{2}$ and Martine L. M. Lamfers ${ }^{1, * \mathbb{D}}$ \\ 1 Department of Neurosurgery, Brain Tumor Center, Erasmus Medical Center, Wytemaweg 80, \\ 3015 CN Rotterdam, The Netherlands; 1.hofman@students.uu.nl \\ 2 Department of Neurosurgery, Brigham and Women's Hospital, Harvard Medical School, 75 Francis St., \\ Boston, MA 02115, USA; slawler@bwh.harvard.edu \\ * Correspondence: m.lamfers@erasmusmc.nl; Tel.: +31-010-703-5993
}

Citation: Hofman, L.; Lawler, S.E.; Lamfers, M.L.M. The Multifaceted Role of Macrophages in Oncolytic Virotherapy. Viruses 2021, 13, 1570. https://doi.org/10.3390/v13081570

Academic Editors: Elizabeth Ilett and Fiona Errington-Mais

Received: 22 June 2021

Accepted: 30 July 2021

Published: 9 August 2021

Publisher's Note: MDPI stays neutral with regard to jurisdictional claims in published maps and institutional affiliations.

Copyright: () 2021 by the authors. Licensee MDPI, Basel, Switzerland. This article is an open access article distributed under the terms and conditions of the Creative Commons Attribution (CC BY) license (https:// creativecommons.org/licenses/by/ $4.0 /)$.

\begin{abstract}
One of the cancer hallmarks is immune evasion mediated by the tumour microenvironment (TME). Oncolytic virotherapy is a form of immunotherapy based on the application of oncolytic viruses (OVs) that selectively replicate in and induce the death of tumour cells. Virotherapy confers reciprocal interaction with the host's immune system. The aim of this review is to explore the role of macrophage-mediated responses in oncolytic virotherapy efficacy. The approach was to study current scientific literature in this field in order to give a comprehensive overview of the interactions of OVs and macrophages and their effects on the TME. The innate immune system has a central influence on the TME; tumour-associated macrophages (TAMs) generally have immunosuppressive, tumoursupportive properties. In the context of oncolytic virotherapy, macrophages were initially thought to predominantly contribute to anti-viral responses, impeding viral spread. However, macrophages have now also been found to mediate transport of OV particles and, after TME infiltration, to be subjected to a phenotypic shift that renders them pro-inflammatory and tumour-suppressive. These TAMs can present tumour antigens leading to a systemic, durable, adaptive anti-tumour immune response. After phagocytosis, they can recirculate carrying tissue-derived proteins, which potentially enables the monitoring of OV replication in the TME. Their role in therapeutic efficacy is therefore multifaceted, but based on research applying relevant, immunocompetent tumour models, macrophages are considered to have a central function in anti-cancer activity. These novel insights hold important clinical implications. When optimised, oncolytic virotherapy, mediating multifactorial inhibition of cancer immune evasion, could contribute to improved patient survival.
\end{abstract}

Keywords: cancer immunotherapy; oncolytic virotherapy; tumour microenvironment; innate immune system; tumour-associated macrophages; M1/M2 phenotypic shift; anti-tumour immunity

\section{Introduction}

Increasing research into the role of the immune system in tumour formation and progression has revealed immune cell evasion to be a central cancer hallmark [1]. This has led to the development of cancer immunotherapies designed to counteract the immunosuppressive characteristics of the tumour microenvironment (TME) and to target tumour antigens. Oncolytic virotherapy is a form of immunotherapy and refers to the administration of viruses that conditionally replicate in tumour cells and activate the immune system [2]. However, the type of immune stimulation induced by oncolytic viruses (OVs) may affect the therapeutic outcome, either by inhibiting the establishment of viral infection or by inducing an anti-tumour immune response [3]. The aim of this review is to explore and elucidate the role of macrophage-mediated responses in the interaction with OVs and the efficacy of oncolytic virotherapy. Understanding the host response is clinically relevant, rendering clues for novel strategies to potentially optimise therapeutic outcomes. 


\section{Tumour Microenvironment (TME)}

Molecular alterations driving cancer growth affect not only the tumour cell but also cells in its environment. Tumour cells have evolved multiple strategies for immune evasion, including disruption of interferon (IFN) signalling [4,5] and secretion of immunosuppressive factors [6]. Other cells in the TME subsequently acquire evasive immune programmes. These heterologous cell types can actively affect the clinical response to treatments, thus constituting an important determinant in therapeutic outcome [7].

\subsection{Innate Immunity in the TME}

In the TME, macrophages play a central role in regulating other components of the immune system and are present at all stages of tumour progression [8]. Most tumourinfiltrating macrophages are derived from blood monocytes, that continuously renew non-proliferating local macrophages $[9,10]$. The presence of chemokine $\mathrm{C}-\mathrm{C}$ motif ligand 2 (CCL-2), or monocyte chemoattractant protein 1 (MCP-1), in the TME, produced by both tumour cells and stromal cells, has been shown to attract macrophages and subsequently maintain chemotaxis by stimulating these macrophages to also secrete CCL-2 [11]. Clinical data suggest that high macrophage density within the TME correlates with a poor prognosis [12] and poor response to treatment [13-15].

Tumour-associated macrophages (TAMs) are among the most prevalent tumourinfiltrating immune cells, comprising up to $50 \%$ of the tumour mass $[12,16]$. In order to exert their multiple functions, macrophages can adopt divergent phenotypes with their polarisation states, which can be broadly termed M1 and M2. This dichotomy, however, simplifies a spectrum of intermediate phenotypes that macrophages acquire through continuous and dynamic microenvironmental signalling [17]. The classically activated M1 phenotype primarily has inflammatory properties and exhibits active signalling involving signal transducer and activator of transcription 1 (STAT1), interferon regulatory factor 5 (IRF5), and nuclear factor k-light-chain enhancer of activated B-cells (NF-kB). This results in the upregulation of major histocompatibility complex class II (MHC-II) and co-stimulatory molecules [18,19]. M1 macrophages recruit and activate other inflammatory immune cells such as natural killer (NK) cells and dendritic cells (DCs) [20]. Through phagocytosis, M1 macrophages can mediate the (cross-)presentation of antigens to elicit an adaptive immune response. M1-like macrophages are considered tumour-suppressive since they can induce tumour cell death directly through macrophage-mediated cytotoxicity or indirectly by instigating an immune response against tumour-associated antigens (TAAs). The alternatively activated M2 phenotype exhibits active STAT6-IRF4 signalling [18] and exerts wound healing and repair functions [21]. This is associated with the secretion of extracellular matrix remodelling molecules and immunosuppressive cytokines, such as interleukin 10 (IL-10) and transforming growth factor $\beta$ (TGF- $\beta$ ) [20]. These macrophages enable efferocytosis of apoptotic cells, clearing them without inducing an immune response [22]. M2 macrophages also express proliferation-stimulating [23] and pro-angiogenic [10] signals, features that support tumour growth and metastasis [24-29].

In vivo, the diversity of TAMs is not yet fully explored [30]. Many tumours have upregulated expression of CD47, a cell surface molecule that interferes with phagocytosis. This indicates that phagocytic processes, associated with the presence of M1-like macrophages, could be active in the TME, however, they are counteracted by immune evasive strategies developed through selection pressure [31]. These findings illustrate the intrinsic functional plasticity of macrophages and their potential to be converted into other subtypes in response to changing environmental conditions [32]. The phagocytic activity of M1 macrophages contributes to their antigen-presenting cell (APC) properties, which gives them a bridging function linking innate and adaptive immune systems [17].

\subsection{TAMs Affect Adaptive Immunity in the TME}

TAMs can communicate with the adaptive immune system through the production of immunosuppressive cytokines, including chemokines that recruit regulatory T-cells 
( $\left.\mathrm{T}_{\mathrm{REG}} \mathrm{s}\right)$. TAMs and $\mathrm{T}_{\mathrm{REG}} \mathrm{S}$ further contribute to local adaptive immunosuppression by secreting IL-10, which functionally impairs infiltrating T-cells by interfering with their production of pro-inflammatory IFN- $\gamma[33,34]$. In conjunction with IL-10 signalling, T-cell expression of negative regulators of T-cell activation such as programmed cell death protein 1 (PD-1) is induced [35]. It has been demonstrated that the depletion of TAMs, but not of normal tissue macrophages, restores tumour-infiltrating cytotoxic T-lymphocyte (CTL) responses and suppresses tumour progression [9].

In summary, cancer immune evasion is initiated by molecular aberrations in tumour signalling pathways, which influences local innate and adaptive immune cells. TAMs play a central role in immune regulation and can adopt divergent phenotypes depending upon their polarisation status acquired through microenvironmental signalling. Generally, they support tumour growth through their immunosuppressive properties.

\section{Oncolytic Virotherapy}

The suppressive characteristics of the TME have provided a rationale for targeting the immune system, which has led to immunomodulation as a therapeutic strategy. OVbased immunotherapies are showing great promise for various cancer types, with the first OVs making it to registration or receiving fast-track designation by the U.S. Food and Drug Administration (FDA) [36]. Both naturally tumour-selective or oncotropic as well as engineered OVs are under investigation. The effects of $\mathrm{OV}$ application are a reflection of the biology of natural viruses and their (co-)evolved interactions with the host and its immune system [37]. OVs, therefore, represent a class of therapeutic agents that can affect anti-cancer activity through a dual mechanism of action of cell lysis and immune stimulation.

\subsection{Oncolysis and Immunogenic Cell Death (ICD)}

Tumour cell lysis was long considered the predominant therapeutic mechanism of OVs. In this setting, constitutive viral replication would be required until each tumour cell has been eliminated. It was widely assumed that the host's immune system limits the clinical efficacy of oncolytic virotherapy by prematurely eradicating the viruses [38]. Now, the importance of the immune system in its anti-cancer activity is well-recognised [39]. Antiviral responses and anti-tumour responses were both found to be induced by OVs. These immune responses were shown to improve overall therapeutic outcome [40]; survival advantages seen in immunocompetent tumour models were lost in immunodeficient and immunosuppressed models [41-43]. The central aim of OV research has, therefore, shifted from the induction of oncolysis to the induction and stimulation of anti-tumour immune responses.

Although the activity exerted by OVs extends beyond the infection of individual tumour cells, some degree of viral replication and oncolysis is required to establish subsequent immune activation. Moreover, anti-cancer activities are connected by the propensity of many OVs to induce immunogenic cell death (ICD), which is characterised by the exposure of damage- or pathogen-associated molecular patterns (DAMPs and PAMPs), and the release of cytokines, including type I IFNs and IFN- $\gamma$ [44-47]. In addition to these danger signals, infected tumour cells will release OV progeny and TAAs, together acting as potent activators of the immune system.

\subsection{Immune-Mediated Mechanisms}

The immune responses that OVs induce are two-sided; therapeutic effects are dampened by the immune system naturally responding to deactivate the virus and promoted by an anti-tumour response. OV replication within the TME confers a three-way interaction between tumour cells, OVs, and the immune system establishing a critical balance that determines the therapeutic outcome.

An immediate, humoral host response against the applied OV is mediated by complement activation and pre-existing antibodies against prevalent human viruses-or their induction through multiple administrations. This could result in neutralisation, opsonisa- 
tion, and rapid clearance of free OV particles and infected cells [48]. Intrinsic, intracellular defence is induced through pattern recognition receptors (PRRs), such as Toll-like receptors (TLRs), that are activated upon PAMP recognition [49]. TLRs signal via the myeloid differentiation primary response protein 88 (MYD88), which leads to activation of the transcription factor NF- $\mathrm{KB}$ inducing upregulated expression of MHC-I [50] and transcription of pro-inflammatory cytokines [51]. Virus infection leads to activation of innate immune cells such as macrophages, DCs and NK cells [52]. Both inflammation and cellular innate immune mediators in the TME form an extracellular anti-viral barrier, in addition to the cancer type-dependent density of the extracellular matrix that physically contributes to the restriction of viral spread [53]. These activated cells affect the lysis of OV-infected cancer cells as well as provide a link to adaptive immune cells that are recruited by the inflammatory TME and that react against virus-specific antigens [54]. These responses directed against the virus may also directly contribute to the anti-cancer activity. It is now proposed that innate defence, through secretion of pro-inflammatory cytokines, may have cytotoxic effects on other uninfected tumour cells [55-57]. Moreover, a correlation between anti-viral and anti-tumour T-cell responses suggests 'epitope spreading', where a strong response against a viral antigen leads to effects against other antigens nearby, indirectly eliciting an anti-tumour response [58].

Anti-viral responses generally convert immunologic tolerance to active inflammation in the TME and hence enable the induction of an anti-tumour response. As viral progeny and TAAs are released into the TME and circulation, these antigens can be taken up and processed by APCs, leading to antigen presentation to T- and B-cells. This may elicit an adaptive response against virus-specific antigens as well as against tumour cells expressing TAAs. Administration of OVs has resulted in tumour regression and disease control in injected and distant non-injected tumours [47,59-62]. Such abscopal effects are attributed to a systemic immune response that has been shown to be T-cell-mediated [41,59,62-66]. Accordingly, OVs are considered in situ vaccines.

Thus, the suppressive TME allows for immunomodulation as a therapeutic strategy. For oncolytic virotherapy, anti-cancer activity was initially thought to consist predominantly through direct oncolytic cell death, rendering anti-viral immune responses an impediment. With the application of immunocompetent animal models, it was discovered that OV-induced ICD elicits inflammation, affecting the suppressive TME, which ultimately enables innate immune cell cytotoxicity and the induction of adaptive T-cell-mediated anti-tumour responses.

\section{OV-Induced Macrophage-Mediated Responses}

The balance between anti-viral and anti-tumour immune responses ultimately determines the anti-cancer efficacy of oncolytic virotherapy. A role in initial anti-viral responses is mainly attributed to OV-induced innate immunity. The reciprocal impact of OVs on macrophages is dynamic, rendering the role of macrophage-mediated responses in the efficacy of oncolytic virotherapy under investigation.

\subsection{Obstructive Macrophage Responses}

In early response to oncolytic virotherapy, macrophages can have a barrier function that limits the delivery and spread of OVs from the site of administration to the tumour and within the TME. Rapidly responding to PAMPs, systemic monocytes and macrophages with an inflammatory M1 phenotype may mediate an anti-viral reaction [19]. Receptor-mediated, accelerated clearance is elicited by complement proteins and antibodies opsonising OV particles, blocking their ability to interact with cellular receptors and facilitating their recognition by macrophages [67]. Within the tissue, macrophages exhibit anti-viral activity through the production of type I IFNs, as was substantiated by the observation that local depletion reduces type I IFN production [68]. Phagocytosis of OVs results directly in the clearance of OV particles [69] and of infected tumour cells, or indirectly through viral antigen presentation and induction of adaptive immunity. In glioblastoma multiforme 
(GBM) mouse models, M1 microglia (brain-resident macrophages) have been found to clear oncolytic vaccinia virus (VV) particles by immediate uptake after intratumoural delivery [70]. Together, these results led to the notion that enhanced therapeutic efficacy may require specific suppression or depletion of these innate immune cells - extending upon the trend of generally restraining the immune system in effectuating anti-viral immune responses. The use of innate immunomodulatory agents, or the use of OVs as vectors encoding proteins that directly interfere with anti-viral defence molecules, has been shown to increase OV replication, spread, and direct oncolysis [71].

A first immunosuppressive agent investigated in conjunction with OVs for general suppression of the innate immune system is cyclophosphamide (CPA), which is, notably, also an approved anti-cancer chemotherapeutic. Co-administration was shown to allow for OV dose reduction [72] and increased the number of infected cancer cells and viral replication for several OVs in different tumour models [73,74]. CPA pre-treatment has been found to increase viral propagation, oncolysis and therapeutic efficacy, suppressing mRNAs of several anti-viral cytokines such as IFN- $\alpha /-\beta,-\gamma$ and TNF- $\alpha$ in peripheral blood mononuclear cells [75], intratumoural phagocyte infiltration and IFN- $\gamma$ production [76], as well as B-cell responses $[77,78]$, while increasing CTL infiltrates and inducing type 1 helper $\mathrm{T}\left(\mathrm{T}_{\mathrm{H}} 1-\right)$ cell immunity on a systemic level [79]. Further, it has been demonstrated to specifically mediate ablation of the TAM population [80]. The application of CPA in combination with complement inhibitor cobra venom factor, suppressing both cellular and humoral innate responses, effectuated enhanced viral infection and propagation of an oncolytic herpes simplex virus (HSV-) 1 within tumours in vivo and consequently increased the life span of GBM-bearing rats [81]. TGF- $\beta$ treatment, known to inhibit NK cells, inflammatory macrophages, and microglia, resulted in enhanced oncolytic HSV-1 titers and suppression of tumour growth in syngeneic murine GBM models [82].

A similar increase in OV titers in the TME could be achieved by direct depletion of macrophages and microglia. This depletion has been investigated as a strategy to enhance the systemic delivery of oncolytic virions [83]. A commonly used approach consists of the application of clodronate encapsulated in liposomes that are engulfed by phagocytic cells resulting in intracellular accumulation and apoptosis [84]. Studies on intratumoural injection of oncolytic HSV-1 in mouse and rat GBM models demonstrated up to a fivefold augmented viral replication after clodronate treatment [85]. Blocking the integrin $\beta 1$ receptor, expressed on the surface of macrophages, has been combined with oncolytic HSV treatment in breast cancer and glioma xenograft models. This combination decreased IFN signalling and pro-inflammatory cytokine induction in tumour cells and inhibited migration of macrophages, resulting in enhanced viral replication and cytotoxicity [86].

These findings suggested that the anti-cancer activity of OVs may specifically be impaired by macrophage-mediated responses. However, it is important to consider additional and alternative interpretations. First of all, the majority of data have been obtained using murine models, and murine in vivo studies have limited translational applications with regard to macrophages, as monocytes in mice differ from those in humans $[87,88]$. Furthermore, many aforementioned studies made use of athymic animal models to study the effects of immunosuppressive treatments. As a result, their negative impact on (adaptive) immune responses in oncolytic virotherapy was not exposed. In the case of immunocompetent models and administration of chemotherapeutic CPA, there might be pleiotropic effects on therapeutic efficacy. CPA has direct anti-cancer activity, and high dosages result in potent cytotoxicity and (innate) immunosuppression-whereas low dosages achieve immunostimulatory effects that include the depletion of suppressive $T_{\mathrm{REG}} \mathrm{s}$ and expansion of antigen-specific T-cells $[79,89]$. Moreover, independent of dosage, CPA exerts proimmunogenic activities on tumour cells, inducing hallmarks of ICD [90]. This potentially enhances anti-tumour responses [64].

Thus, anti-viral immunity counteracting oncolytic virotherapy efficacy can be mediated by macrophages, but the notion that they predominantly contribute to obstructive responses could be nuanced by the choice of tumour models and pharmacological adjuvant. 


\subsection{Supportive Macrophage Responses}

\subsubsection{Tumour Infiltration}

Upon OV infection of the tumour, intrinsic anti-viral signalling activates the transcription factor NF- $\mathrm{kB}$, ultimately leading to the expression of, amongst others, the chemokine CCL-2, which mediates constitutive macrophage infiltration in the TME [11]. Macrophage infiltrates are found early after OV administration [42,91]. Infection with oncolytic VV GLV-1h68 of human colorectal cancer xenografts in mice, adenovirus Delta24-RGD in a syngeneic mouse GBM model, multiple HSV-1s in orthotopic GBM xenografts, and recombinant orthopoxvirus in mouse models of colon cancer were all shown to induce an increased TAM population $[43,57,92,93]$. Treatment with an IL-12-encoding HSV-1 led to an enhanced influx of both activated macrophages and T-cells when compared with control OVs and improved survival in a murine glioma model [94]. The pro-inflammatory environment mediated by OVs could be potentiated by interactions with infiltrated macrophages [95,96], supporting OV therapy as substantiated by immune cell depletion studies [97]. In immunocompetent mouse models of renal adenocarcinoma and melanoma treated with the murine oncolytic adenovirus dlE102, tumour volumes were significantly reduced, and a pro-inflammatory TME was induced. They presented an increased infiltration of TAMs, NK cells, and lymphocytes, also harbouring fewer tumour-infiltrating lymphocytes expressing PD-1, a major regulator of T-cell exhaustion [98]. In recurrent GBM patients treated with oncolytic $\mathrm{H}-1$ poliovirus (PV), markers of microglia and macrophage activation were detected in infected tumours [99]. In GBM patients treated with oncolytic adenovirus Delta24-RGD, cerebrospinal fluid samples showed cytokine levels indicative of an inflammatory TME, leading to further recruitment of immune cells and inflammation [100].

In summary, constitutive macrophage recruitment to the TME is regulated by the expression of CCL-2, which is induced by pro-inflammatory anti-viral signalling pathways. This macrophage infiltration has been observed in multiple in vivo tumour models treated with various OVs.

\subsubsection{Phenotypic Shift}

Conventional therapies have been observed to further polarise macrophages towards an M2 phenotype [101]. This plasticity of resident and newly recruited macrophages in the TME could also be utilised to target and polarise TAMs towards an M1 phenotype, resulting in an anti-tumour environment [102]. Targeting TAMs through the inhibition of colony-stimulating factor-1 receptor (CSF-1R), a key macrophage signalling pathway, has been shown to counteract macrophage-mediated immune suppression by inhibiting the differentiation, proliferation and survival of M2 macrophages [103,104]. Since the presence of OVs has been demonstrated to yield an inflammatory TME, the notion was that virotherapy could be used as an inducer of M1 signalling in macrophages [105]. A phenotypic shift can be achieved by OVs through concerted action: the presence of OV particles contributes to M2 marker downregulation and soluble factors secreted from OV-infected cancer cells induce M1 marker upregulation [100]. M2-associated IRF4 and M1-associated IRF5 compete for the MYD88 complex that is also an adaptor involved in all anti-viral TLR signalling [106,107]. Through this pathway, PAMPs binding to TLRs can induce a shift in phenotype; macrophages are suggested to detect viral genetic elements by TLR9, OV-infected tumour cells by TLR2, activating IRF5 which, via the MYD88-IRF5 complex, upregulates NF-kB, IRF5, and IRF7. This ultimately inhibits M2-related signalling and leads to M1-associated gene transcription [100,108].

It has been demonstrated that tumour-resident macrophages increase in number and gain more M1 characteristics upon treatment with OVs in divergent mouse models, including oncolytic adenovirus in orthotopic GBM models [43,109] and anaplastic thyroid carcinoma xenograft models [110], as well as oncolytic HSV-1 in athymic and syngeneic models for GBM, breast cancer, and melanoma [57,97,111-113]. Moreover, tumour cell death mediated by the oncolytic mumps and measles paramyxoviruses was shown to be affected by monocyte-derived macrophage responses in murine breast cancer models 
irrespective of the polarisation state of the initial TAM population [114]. Immune cell depletion studies in murine GBM models demonstrated that these macrophages are essential for achieving therapeutic effects [97]. In clinical trials in GBM patients, Delta24-RGD, autonomous protoparvovirus $\mathrm{H}-1$, and vocimagene amiretrorepvec (Toca 511) treatments were shown to induce a phenotypic shift in GBM TAMs, accompanied by pro-inflammatory cytokine secretion $[100,115,116]$.

Recombinant OVs encoding immunomodulatory molecules provide an approach to augment this phenotypic shift. Polarisation towards M2 macrophages can be directly impaired or reversed, with an IFN-encoding [117] or soluble TGF- $\beta$ receptor-encoding oncolytic viral vector. In human breast cancer bone metastases in nude mice, M2 macrophage activity and tumour progression were reduced using this approach [118]. Oncolytic virotherapy treatment of a mouse GBM model combined with an anti-PD- 1 and an anticheckpoint blockade of CTL antigen 4 (CTLA-4) immunotherapy was associated with both macrophage influx and M1-like polarisation and yielded synergistic therapeutic activity for which macrophages were required [97]; these immunostimulatory M1 phenotypes enable the induction of other adaptive immune responses.

Thus, the phenotypic spectrum of macrophages is plastic and dependent on signals from the microenvironment. TAMs have been shown to downregulate M2-associated and upregulate M1-associated markers upon OV treatment, which can be substantiated by the molecular pathways involved in anti-viral signalling and their phenotypic plasticity.

\subsubsection{Phagocytosis and Antigen Presentation}

The OV-induced release of PAMPs, DAMPs, and cytokines into the TME promotes the maturation of APCs [119] such as M1 macrophages [57]. Maturation yields upregulated MHC-II, co-stimulatory molecules, and chemokine receptors. TAMs in a Delta24-RGDtreated GBM patient have been found to contain hexon peptides, one of the viral capsid proteins [100]. It has been demonstrated that macrophages are resistant to wild-type adenoviral replication [120], and similarly, TAMs have been shown to be non-permissive to oncolytic adenoviral replication. Thus, the observed hexon-positivity of these TAMs was presumably caused by phagocytosis. Co-culturing of in vitro polarised macrophage phenotypes with Delta24-RGD-infected tumour cells demonstrated that M1 macrophages have greater phagocytosis capacity [100], suggesting a synergistic influence of OV-induced phenotypic shift, phagocytosis, and maturation, after which digested peptides can be loaded onto MHC-II. CD169 ${ }^{+}$macrophages, rather than DCs, have been identified in T-cell lymphoma mouse models as being essential APCs for the induction of CD8 ${ }^{+}$T-cellmediated anti-tumour immune responses [121].

The inflammatory TME mediates the recruitment and activation of T-cells [42,47,91], to which antigens can be presented either in the TME or after lymphoid migration [122-124]. M1 macrophages are related to inducing a $\mathrm{T}_{\mathrm{H}} 1$-cell response, and subsequently, activated $\mathrm{CD}^{+}$T-cells become CTLs, that have the ability to migrate to sites of tumour growth. This adaptive immune response has been associated with T-cell clones circulating and inducing lytic cell death of TAA-expressing cancer cells, both infected and uninfected [125], facilitated by the upregulation of MHC-I on cells with active NF- $\kappa \mathrm{B}$ signaling. It has also been associated with an immune-mediated bystander effect, meaning that the local release of cytotoxic molecules by CTLs might induce the death of adjacent cancer cells [126]. This T-cell-mediated anti-tumour efficacy has been confirmed by studies applying cytokine-armed oncolytic HSV-1 on neuroblastoma using syngeneic models compared to athymic mice [127]. Priming of CD8 ${ }^{+}$T-cells can be further enhanced by antagonising tumour-induced suppression of phagocytosis with antibodies against CD47, facilitating antigen presentation by macrophages [128]. An oncolytic VV engineered to counteract antiphagocytic CD47, replicated in tumour cells and redirected both M1 and M2 macrophages to tumour cells in vitro. Treatment of an immunocompetent osteosarcoma mouse model with this OV resulted in a significant survival advantage compared to the controls [129]. Oncolytic HSV-1 armed with an MHC-like molecule expression cassette directly stimulates 
macrophage-mediated antigen processing and presentation and accumulation of activated T-cells [130].

Taken together, macrophages shifted to an M1 phenotype after OV treatment can, through phagocytosis, mediate the (cross-)presentation of antigens released by ICD to elicit an adaptive immune response. This results in systemic, durable anti-tumour immunity, as observed in divergent tumour models.

\subsubsection{Viral Transport and Therapy Monitoring Tool}

The extent and type of host anti-viral responses to OVs are primarily determined by the route of administration. Delivery preference is dependent on tumour type and OV species, but often, OVs are directly delivered through intratumoural injection [131]. Nonetheless, tumours are not always accessible, and systemic delivery may be required. Systemic administration of OVs is relatively simple, reaching multiple tumour sites, potentially treating or preventing metastases. However, this application leads to rapid recognition and elimination of the OVs by the immune system, which has been shown with oncolytic measles virus (MV) [132], Newcastle disease virus (NDV) [133], VV [134], and adenovirus [135]. Clearance could be due to humoral responses, but hepatic and splenic sequestration and absence of extravasation might also impair delivery and spread [53].

This barrier could be overcome using technologies such as liposomes and exosomes to mask the OVs and evade recognition by the immune system [136,137]. Another strategy is to mediate transport of OVs with carrier cells, which would confer both protection from neutralisation and opsonisation as well as tumour homing, without losing the biological activity of either virus or carrier cell. Various cell types have been studied as potential virus carriers, including irradiated human teratocarcinoma cells for HSV-1716 [138], neural stem or precursor cells for oncolytic HSV-1 rRp450 [139], adenovirus CRAd-SpK7 [135,140,141] and orthopoxvirus CF33 [142], mesenchymal stem cells for oncolytic MV [143], adenovirus [144,145] and HSV [146], blood and hepatic mononuclear cells as well as lymphokine-activated (immature) DCs and NK cells for reovirus [147-149], and a T-cell line for Delta24-RGD [150]. They are all hypothesised to home to the TME after infection or loading ex vivo. Virus particles have been found to also naturally associate with circulating cells after systemic delivery [151]. The potential of carrier cells can vary upon their permissiveness to $\mathrm{OV}$ infection, natural capacity to home to tumour growth sites, ability to protect OVs from immune detection in the circulation, and transmission of OV particles to cancer cells [37]. More recently, macrophages have also been found to mediate OV transport [152]. They can be manipulated using a hypoxia-regulated construct to control oncolytic adenovirus replication. Specificity is achieved by macrophages homing to tumour-associated hypoxia upon which OV replication is activated [153]. They are also infected ex vivo [154] and reinfused. Notably, monocytes and macrophages have been found to capture circulating reovirus through antibody binding in vivo [155]. As macrophages naturally migrate to areas of tissue destruction and are actively recruited to the TME, this process contributes to the tumour targeting of systemically delivered OVs $[10,156,157]$.

Lastly, a recent study revealed that subsets of monocytes carrying tumour- or tissuespecific proteins in their phagolysosomes could be detected in the blood of brain tumour and ischemic stroke patients [158]. These assumed recirculating tissue macrophages derived from areas of tissue damage could, in the case of virotherapy, also carry OV-derived proteins [100]. This approach may, in the future, offer a tool to monitor the presence and duration of OV replication in the tumour. Together, these findings on macrophagemediated transport of virus particles or proteins to and from areas of tissue damage open new avenues for the delivery and monitoring of oncolytic virotherapy.

\section{Conclusions and Future Directions}

Based on current understanding, there is a multifaceted role for macrophage-mediated responses in the efficacy of oncolytic virotherapy as a cancer treatment (Figure 1). 


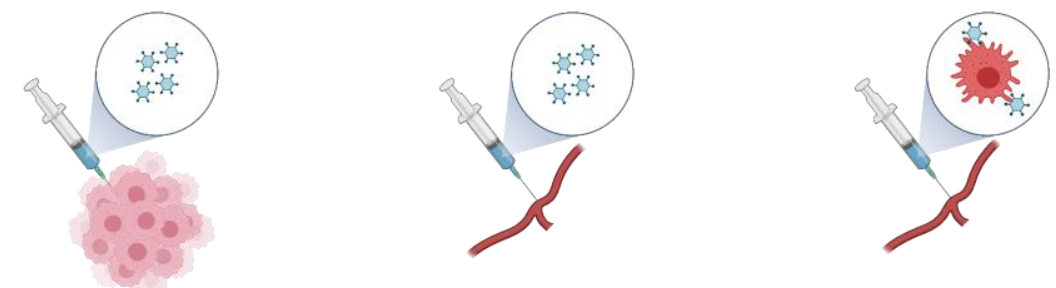

(2)

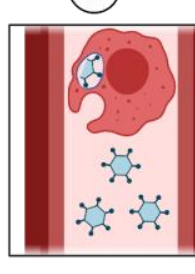

(5)

(iil

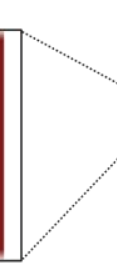

s

$\int_{3}^{2} \mathrm{~s}^{2}$

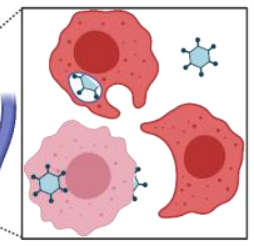

(2)

(6)

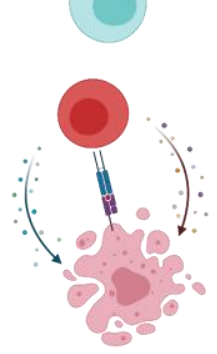

(3) $\downarrow$ IFNy
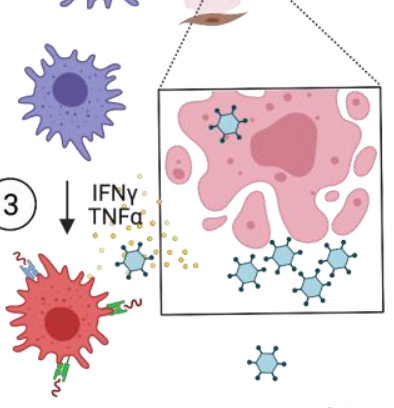

西

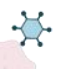

\%
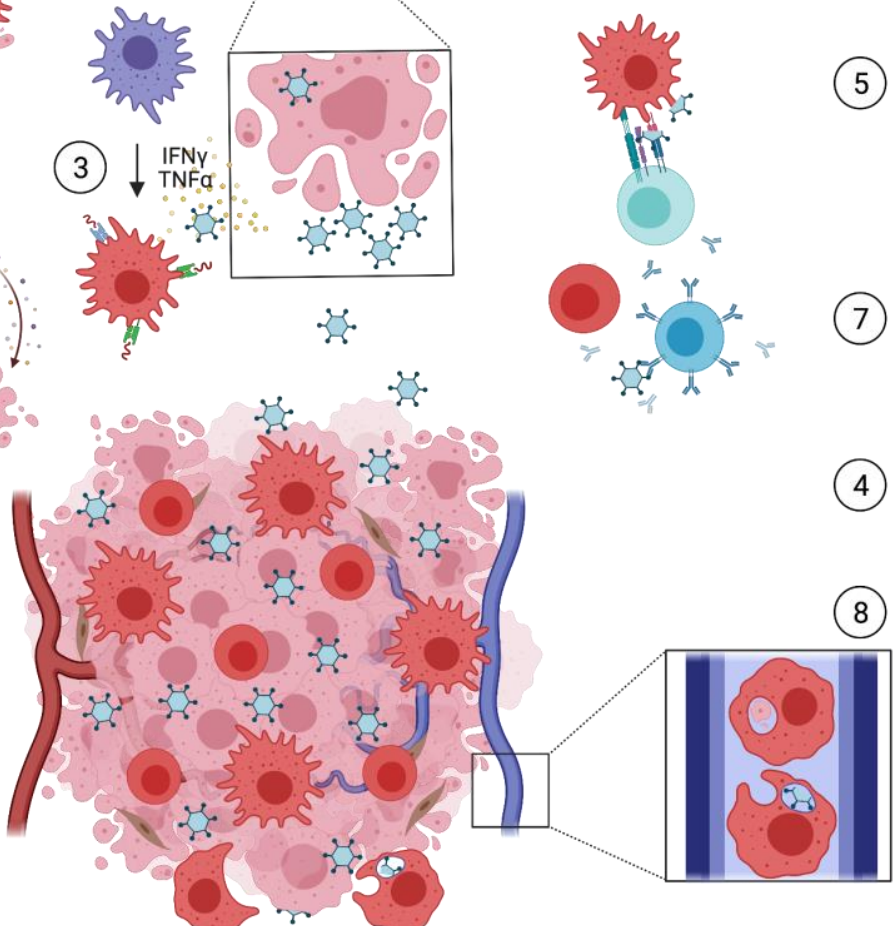

Figure 1. Oncolytic viruses (OVs) exert not only oncolysis, but also immune responses in which macrophages are important mediators involved in a number of key processes. Through intratumoural injection, systemic administration, or via cellular carriers (1), delivery of OVs to the immunosuppressive tumour microenvironment (TME) can be established. This is restricted by innate phagocytic activity of macrophages through clearance of virus particles and virally infected cells (2). Cancer cell infection and replication lead to immunogenic oncolysis, resulting in viral progeny spread, inflammation and antigen release. Cytokines cause a macrophage shift from a tumour-supportive M2 towards a pro-inflammatory M1 phenotype (3), sustaining inflammation. More immune cells are recruited and infiltrate the TME (4), enabling macrophage-mediated antigen presentation to T-cells (5). This adaptive immune response is multifaceted and can entail both a supportive response against tumour-associated antigens (TAAs), resulting in cytotoxic cancer cell death (6), and an obstructive response against viral antigens, facilitating T- and B-cell clearance of infected cells and virus particles (7). Macrophages may also return to the circulation carrying tumour- and virus-derived proteins and offer a tool for monitoring oncolytic virotherapy (8). 
The presence of TAMs is generally associated with a poor prognosis of human cancer patients by having an immunosuppressive influence in the TME. In oncolytic virotherapy treatment, macrophages have historically been considered to predominantly contribute to anti-viral responses, which could be nuanced and partly explained by the applied tumour models and assessed pharmacological adjuvant. At present, the insight is that macrophages also mediate virotherapy-supporting responses. They may play a crucial role in establishing adaptive anti-tumour immunity. In a variety of OV-treated tumours, macrophage infiltrates are polarised towards the pro-inflammatory, tumour-suppressive M1 phenotype. This can potentiate oncolytic virotherapy treatment through phagocytosis of (infected) cancer cells and subsequent antigen presentation, enabling a T-cell-mediated anti-tumour immune response. More recently, systemic macrophages have been found to additionally facilitate viral transport by the capturing of circulating OVs and the transmission of OV particles to tumour sites. TAMs also return to the bloodstream carrying tissue-derived proteins after completing scavenging activities in damaged tissue, which potentially enables the monitoring of OV replication in the TME. The increasing number of identified macrophage responses implies that understanding the interaction between macrophages and viruses in oncolytic virotherapy is not yet complete and is continuously evolving.

The diverse and dynamic aspects of $\mathrm{OV}$ infection-related immune responses have led to discordant findings on the role of macrophage-mediated responses in oncolytic virotherapy efficacy. Anti-viral and anti-tumour responses often encompass overlapping immunological pathways. However, modulating the equilibrium between these responses, aiming to maximally dampen anti-viral responses while retaining anti-tumour responses, is challenging and poorly understood but might be central to improve oncolytic virotherapy effectiveness. Specific pharmacological suppressors of the innate immune system could, for instance, be applied at low doses prior to, or at the time of, OV administration, transiently exerting their effects in interfering with anti-viral responses [129,159-161]. This approach is currently being investigated in a clinical phase I trial testing oncolytic HSV-1 rQNestin with single-dose CPA pre-treatment [162]. Valproic acid, an FDA-approved anti-epileptic agent with histone deacetylase inhibitory function, is also in development for treating cancer and prevents the transcriptional activity of IFN-stimulated genes [91]. Furthermore, while commonly applied clodronate liposomes non-specifically deplete macrophages, also disabling their indirect anti-cancer activity [111], a novel, more selective agent could, for instance, interfere with systemic macrophage function or characteristic phagocytosis pathways in receptor-mediated viral clearance. However, insights suggest an important role for macrophages as cellular carriers of OVs and indicate that initial restriction of systemic macrophage functions may also have unpredicted negative effects on therapeutic outcomes.

Over time, sufficient inflammation must be permitted and, when the restriction on the innate immune system has been removed, an anti-tumour response can be developed. Viral pharmacokinetics, pharmacodynamics, and kinetics of innate immune suppression in relation to the number of initial viral replication cycles require further investigation, ultimately supported by mathematical modelling of interactions and making quantitative and substantiated predictions [163]. Moreover, it needs to be elucidated whether this approach would compromise the safety profile. When optimised, this strategy could provide long-term immune-mediated anti-cancer activity.

As might be perceived, there are challenges in the broad clinical implementation of oncolytic virotherapy. In prospective preclinical studies and multi-institutional trials, it is desired - and potentially required, that (clinical) response assessments be standardised to enable comparison. To investigate the role of the innate and adaptive immune system in therapeutic efficacy, standardised analysis of immune infiltrates, circulating immune cells, intratumoural viral replication, and (degree of) ICD might be relevant. Knowing the key players during OV infection in the context of the TME will be critical for developing optimally effective oncolytic virotherapies. 
Author Contributions: Conceptualization, M.L.M.L.; investigation, L.H.; writing-original draft preparation, L.H.; writing-review and editing, L.H., S.E.L. and M.L.M.L., visualization, L.H.; supervision, M.L.M.L. and S.E.L. All authors have read and agreed to the published version of the manuscript.

Funding: This research received no external funding.

Conflicts of Interest: The authors declare no conflict of interest.

\section{References}

1. Hanahan, D.; Weinberg, R.A. Hallmarks of cancer: The next generation. Cell 2011, 144, 646-674. [CrossRef]

2. Harrington, K.; Freeman, D.J.; Kelly, B.; Harper, J.; Soria, J.-C. Optimizing oncolytic virotherapy in cancer treatment. Nat. Rev. Drug Discov. 2019, 18, 689-706. [CrossRef]

3. Filley, A.C.; Dey, M. Immune system, friend or foe of oncolytic virotherapy? Front. Oncol. 2017, 7, 1-8. [CrossRef]

4. Wong, L.H.; Krauer, K.G.; Hatzinisiriou, I.; Estcourt, M.J.; Hersey, P.; Tam, N.D.; Edmondson, S.; Devenish, R.J.; Ralph, S.J. Interferon-resistant human melanoma cells are deficient in ISGF3 components, STAT1, STAT2, and p48-ISGF3g. J. Biol. Chem. 1997, 272, 28779-28785. [CrossRef] [PubMed]

5. Critchley-Thorne, R.J.; Simons, D.L.; Yan, N.; Miyahira, A.K.; Dirbas, F.M.; Johnson, D.L.; Swetter, S.M.; Carlson, R.W.; Fisher, G.A.; Koong, A.; et al. Impaired interferon signaling is a common immune defect in human cancer. Proc. Natl. Acad. Sci. USA 2009, 106, 9010-9015. [CrossRef] [PubMed]

6. Rabinovich, G.A.; Gabrilovich, D.; Sotomayor, E.M. Immunosuppressive strategies that are mediated by tumor cells. Annu. Rev. Immunol. 2007, 25, 267-296. [CrossRef] [PubMed]

7. Junttila, M.R.; De Sauvage, F.J. Influence of tumour micro-environment heterogeneity on therapeutic response. Nature 2013, 501, 346-354. [CrossRef]

8. Noy, R.; Pollard, J.W. Tumor-associated macrophages: From mechanisms to therapy. Immunity 2014, 41, 49-61. [CrossRef]

9. Franklin, R.A.; Liao, W.; Sarkar, A.; Kim, M.V.; Bivona, M.R.; Liu, K.; Pamer, E.G.; Li, M.O. The cellular and molecular origin of tumor-associated macrophages. Science 2014, 344, 921-925. [CrossRef]

10. Movahedi, K.; Laoui, D.; Gysemans, C.; Baeten, M.; Stangé, G.; Van den Bossche, J.; Mack, M.; Pipeleers, D.; In't Veld, P.; De Baetselier, P.; et al. Different tumor microenvironments contain functionally distinct subsets of macrophages derived from Ly6C(high) monocytes. Cancer Res. 2010, 70, 5728-5739. [CrossRef]

11. Nakatsumi, H.; Matsumoto, M.; Nakayama, K.I. Noncanonical pathway for regulation of CCL2 expression by an mTORC1-FOXK1 axis promotes recruitment of tumor-associated macrophages. Cell Rep. 2017, 21, 2471-2486. [CrossRef]

12. Zhang, Y.; Cheng, S.; Zhang, M.; Zhen, L.; Pang, D.; Zhang, Q.; Li, Z. High-infiltration of tumor-associated macrophages predicts unfavorable clinical outcome for node-negative breast cancer. PLoS ONE 2013, 8, e76147. [CrossRef]

13. Hughes, R.; Qian, B.-Z.; Rowan, C.; Muthana, M.; Keklikoglou, I.; Olson, O.C.; Tazzyman, S.; Danson, S.; Addison, C.; Clemons, M.; et al. Perivascular M2 macrophages stimulate tumor relapse after chemotherapy. Cancer Res. 2015, 75, 3479-3491. [CrossRef]

14. De Palma, M.; Lewis, C.E. Macrophages limit chemotherapy. Nature 2011, 472, 303-304. [CrossRef]

15. De Palma, M.; Lewis, C.E. Macrophage regulation of tumor responses to anticancer therapies. Cancer Cell 2013, 23, 277-286. [CrossRef]

16. Andreansky, S.; He, B.; Van Cott, J.; McGhee, J.; Markert, J.M.; Gillespie, G.Y.; Roizman, B.; Whitley, R.J. Treatment of intracranial gliomas in immunocompetent mice using herpes simplex viruses that express murine interleukins. Gene Ther. 1998, 5, 121-130. [CrossRef] [PubMed]

17. Mantovani, A.; Biswas, S.K.; Galdiero, M.R.; Sica, A.; Locati, M. Macrophage plasticity and polarization in tissue repair and remodelling. J. Pathol. 2013, 229, 176-185. [CrossRef]

18. Lawrence, T.; Natoli, G. Transcriptional regulation of macrophage polarization: Enabling diversity with identity. Nat. Rev. Immunol. 2011, 11, 750-761. [CrossRef] [PubMed]

19. Murray, P.J.; Wynn, T.A. Protective and pathogenic functions of macrophage subsets. Nat. Rev. Immunol. 2011, 11, 723-737. [CrossRef] [PubMed]

20. Mosser, D.M.; Edwards, J.P. Exploring the full spectrum of macrophage activation. Nat. Rev. Immunol. 2008, 8, 958-969. [CrossRef]

21. Gordon, S. Alternative activation of macrophages. Nat. Rev. Immunol. 2003, 3, 23-35. [CrossRef]

22. Liu, Y.; Cousin, J.M.; Hughes, J.; Van Damme, J.; Seckl, J.R.; Haslett, C.; Dransfield, I.; Savill, J.; Rossi, A.G. Glucocorticoids promote nonphlogistic phagocytosis of apoptotic leukocytes. J. Immunol. 1999, 162, 3639-3646.

23. Pollard, J.W. Tumor-educated macrophages promote tumor progression and metastasis. Nat. Rev. Cancer 2004, 4, 71-78. [CrossRef]

24. Hagemann, T.; Wilson, J.; Burke, F.; Kulbe, H.; Li, N.F.; Plüddemann, A.; Charles, K.; Gordon, S.; Balkwill, F.R. Ovarian cancer cells polarize macrophages toward a tumor-associated phenotype. J. Immunol. 2006, 176, 5023-5032. [CrossRef] [PubMed]

25. Komohara, Y.; Ohnishi, K.; Kuratsu, J.; Takeya, M. Possible involvement of the M2 anti-inflammatory macrophage phenotype in growth of human gliomas. J. Pathol. 2008, 216, 15-24. [CrossRef]

26. Sousa, S.; Brion, R.; Lintunen, M.; Kronqvist, P.; Sandholm, J.; Mönkkönen, J.; Kellokumpu-Lehtinen, P.-L.; Lauttia, S.; Tynninen, O.; Joensuu, H.; et al. Human breast cancer cells educate macrophages toward the M2 activation status. Breast Cancer Res. 2015, 17, 1-14. [CrossRef] [PubMed] 
27. Wu, A.; Wei, J.; Kong, L.-Y.; Wang, Y.; Priebe, W.; Qiao, W.; Sawaya, R.; Heimberger, A.B. Glioma cancer stem cells induce immunosuppressive macrophages/microglia. Neuro. Oncol. 2010, 12, 1113-1125. [CrossRef] [PubMed]

28. Condeelis, J.; Pollard, J.W. Macrophages: Obligate partners for tumor cell migration, invasion, and metastasis. Cell 2006, 124, 263-266. [CrossRef]

29. Hesketh, A.J.; Maloney, C.; Behr, C.A.; Edelman, M.C.; Glick, R.D.; Al-Abed, Y.; Symons, M.; Soffer, S.Z.; Steinberg, B.M. The macrophage inhibitor CNI-1493 blocks metastasis in a mouse model of Ewing sarcoma through inhibition of extravasation. PLoS ONE 2015, 10, e0145197. [CrossRef]

30. Edin, S.; Wikberg, M.L.; Dahlin, A.M.; Rutegård, J.; Öberg, Å.; Oldenborg, P.A.; Palmqvist, R. The distribution of macrophages with a M1 or M2 phenotype in relation to prognosis and the molecular characteristics of colorectal cancer. PLoS ONE 2012, 7, e47045. [CrossRef]

31. Chao, M.P.; Weissman, I.L.; Majeti, R. The CD47-SIRP $\alpha$ pathway in cancer immune evasion and potential therapeutic implications. Curr. Opin. Immunol. 2012, 24, 225-232. [CrossRef]

32. Stout, R.D.; Suttles, J. Functional plasticity of macrophages: Reversible adaptation to changing microenvironments. J. Leukoc. Biol. 2004, 76, 509-513. [CrossRef]

33. Biswas, S.K.; Mantovani, A. Macrophage plasticity and interaction with lymphocyte subsets: Cancer as a paradigm. Nat. Immunol. 2010, 11, 889-896. [CrossRef]

34. D'Andrea, A.; Aste-Amezaga, M.; Valiante, N.M.; Ma, X.; Kubin, M.; Trinchieri, G. Interleukin 10 (IL-10) inhibits human lymphocyte interferon gamma-production by suppressing natural killer cell stimulatory factor/IL-12 synthesis in accessory cells. J. Exp. Med. 1993, 178, 1041-1048. [CrossRef] [PubMed]

35. Brooks, D.G.; Ha, S.-J.; Elsaesser, H.; Sharpe, A.H.; Freeman, G.J.; Oldstone, M.B.A. IL-10 and PD-L1 operate through distinct pathways to suppress T-cell activity during persistent viral infection. Proc. Natl. Acad. Sci. USA 2008, 105, 20428-20433. [CrossRef] [PubMed]

36. Cook, M.; Chauhan, A. Clinical Application of Oncolytic Viruses: A Systematic Review. Int. J. Mol. Sci. 2020, 21, 7505. [CrossRef] [PubMed]

37. Chiocca, E.A.; Rabkin, S.D. Oncolytic viruses and their application to cancer immunotherapy. Cancer Immunol. Res. 2014, 2, 295-300. [CrossRef] [PubMed]

38. Koks, C.A.E.; De Vleeschouwer, S.; Graf, N.; Van Gool, S.W. Immune suppression during oncolytic virotherapy for high-grade glioma; yes or no? J. Cancer 2015, 6, 203-217. [CrossRef]

39. Sanmamed, M.F.; Chester, C.; Melero, I.; Kohrt, H. Defining the optimal murine models to investigate immune checkpoint blockers and their combination with other immunotherapies. Ann. Oncol. 2016, 27, 1190-1198. [CrossRef]

40. Melcher, A.; Parato, K.; Rooney, C.M.; Bell, J.C. Thunder and lightning: Immunotherapy and oncolytic viruses collide. Mol. Ther. 2011, 19, 1008-1016. [CrossRef]

41. Miller, C.G.; Fraser, N.W. Requirement of an integrated immune response for successful neuroattenuated HSV-1 therapy in an intracranial metastatic melanoma model. Mol. Ther. 2003, 7, 741-747. [CrossRef]

42. Miller, C.G.; Fraser, N.W. Role of the immune response during neuro-attenuated Herpes simplex virus-mediated tumor destruction in a murine intracranial melanoma model. Cancer Res. 2000, 60, 5714-5722.

43. Kleijn, A.; Kloezeman, J.; Treffers-Westerlaken, E.; Fulci, G.; Leenstra, S.; Dirven, C.; Debets, R.; Lamfers, M. The in vivo therapeutic efficacy of the oncolytic adenovirus Delta24-RGD is mediated by tumor-specific immunity. PLoS ONE 2014, 9, e97495. [CrossRef]

44. Diaconu, I.; Cerullo, V.; Hirvinen, M.L.M.; Escutenaire, S.; Ugolini, M.; Pesonen, S.K.; Bramante, S.; Parviainen, S.; Kanerva, A.; Loskog, A.S.I.; et al. Immune Response Is an Important Aspect of the Antitumor Effect Produced by a CD40L-Encoding Oncolytic Adenovirus. Cancer Res. 2012, 72, 2327-2338. [CrossRef] [PubMed]

45. Donnelly, O.G.; Errington-Mais, F.; Steele, L.; Hadac, E.; Jennings, V.; Scott, K.; Peach, H.; Phillips, R.M.; Bond, J.; Pandha, H.; et al. Measles virus causes immunogenic cell death in human melanoma. Gene Ther. 2013, 20, 7-15. [CrossRef]

46. Workenhe, S.T.; Simmons, G.; Pol, J.G.; Lichty, B.D.; Halford, W.P.; Mossman, K.L. Immunogenic HSV-mediated Oncolysis Shapes the Antitumor Immune Response and Contributes to Therapeutic Efficacy. Mol. Ther. 2014, 22, 123-131. [CrossRef]

47. Zamarin, D.; Holmgaard, R.B.; Subudhi, S.K.; Park, J.S.; Mansour, M.; Palese, P.; Merghoub, T.; Wolchok, J.D.; Allison, J.P. Localized oncolytic virotherapy overcomes systemic tumor resistance to immune checkpoint blockade immunotherapy. Sci. Transl. Med. 2014, 6, 226ra32. [CrossRef] [PubMed]

48. Chen, Y.; Yu, D.-C.; Charlton, D.; Henderson, D.R. Pre-existent adenovirus antibody inhibits systemic toxicity and antitumor activity of CN706 in the nude mouse LNCaP xenograft model: Implications and proposals for human therapy. Hum. Gene Ther. 2000, 11, 1553-1567. [CrossRef]

49. Kumar, H.; Kawai, T.; Akira, S. Pathogen recognition by the innate immune system. Int. Rev. Immunol. 2011, 30, 16-34. [CrossRef] [PubMed]

50. Gujar, S.; Dielschneider, R.; Clements, D.; Helson, E.; Shmulevitz, M.; Marcato, P.; Pan, D.; Pan, L.; Ahn, D.-G.; Alawadhi, A.; et al. Multifaceted therapeutic targeting of ovarian peritoneal carcinomatosis through virus-induced immunomodulation. Mol. Ther. 2013, 21, 338-347. [CrossRef] [PubMed]

51. Deb, A.; Haque, S.J.; Mogensen, T.; Silverman, R.H.; Williams, B.R.G. RNA-dependent protein kinase PKR is required for activation of NF-kB by IFN- $\gamma$ in a STAT1-independent pathway. J. Immunol. 2001, 166, 6170-6180. [CrossRef] 
52. Takeuchi, O.; Akira, S. Innate immunity to virus infection. Immunol. Rev. 2009, 227, 75-86. [CrossRef]

53. Russell, S.J.; Peng, K.-W.; Bell, J.C. Oncolytic virotherapy. Nat. Biotechnol. 2012, 30, 658-670. [CrossRef] [PubMed]

54. Guidotti, L.G.; Chisari, F.V. Noncytolytic control of viral infections by the innate and adaptive immune response. Annu. Rev. Immunol. 2001, 19, 65-91. [CrossRef] [PubMed]

55. Beug, S.T.; Tang, V.A.; LaCasse, E.C.; Cheung, H.H.; Beauregard, C.E.; Brun, J.; Nuyens, J.P.; Earl, N.; St-Jean, M.; Holbrook, J.; et al. Smac mimetics and innate immune stimuli synergize to promote tumor death. Nat. Biotechnol. 2014, 32, 182-190. [CrossRef] [PubMed]

56. Breitbach, C.J.; Paterson, J.M.; Lemay, C.G.; Falls, T.J.; McGuire, A.; Parato, K.A.; Stojdl, D.F.; Daneshmand, M.; Speth, K.; Kirn, D.; et al. Targeted inflammation during oncolytic virus therapy severely compromises tumor blood flow. Mol. Ther. 2007, 15, 1686-1693. [CrossRef] [PubMed]

57. Meisen, W.H.; Wohleb, E.S.; Jaime-Ramirez, A.C.; Bolyard, C.; Yoo, J.Y.; Russell, L.; Hardcastle, J.; Dubin, S.; Muili, K.; Yu, J.; et al. The impact of macrophage and microglia secreted TNF $\alpha$ on oncolytic HSV-1 therapy in the glioblastoma tumor microenvironment. Clin. Cancer Res. 2015, 21, 3274-3285. [CrossRef]

58. Kanerva, A.; Nokisalmi, P.; Diaconu, I.; Koski, A.; Cerullo, V.; Liikanen, I.; Tähtinen, S.; Oksanen, M.; Heiskanen, R.; Pesonen, S.; et al. Antiviral and antitumor T-cell immunity in patients treated with GM-CSF-coding oncolytic adenovirus. Clin. Cancer Res. 2013, 19, 2734-2744. [CrossRef]

59. Todo, T.; Rabkin, S.D.; Sundaresan, P.; Wu, A.; Meehan, K.R.; Herscowitz, H.B.; Martuza, R.L. Systemic antitumor immunity in experimental brain tumor therapy using a multimutated, replication-competent herpes simplex virus. Hum. Gene Ther. 1999, 10, 2741-2755. [CrossRef]

60. Heo, J.; Reid, T.; Ruo, L.; Breitbach, C.J.; Rose, S.; Bloomston, M.; Cho, M.; Lim, H.Y.; Chung, H.C.; Kim, C.W.; et al. Randomized dose-finding clinical trial of oncolytic immunotherapeutic vaccinia JX-594 in liver cancer. Nat. Med. 2013, 19, 329-336. [CrossRef]

61. Andtbacka, R.H.I.; Kaufman, H.L.; Collichio, F.; Amatruda, T.; Senzer, N.; Chesney, J.; Delman, K.A.; Spitler, L.E.; Puzanov, I.; Agarwala, S.S.; et al. Talimogene laherparepvec improves durable response rate in patients with advanced melanoma. J. Clin. Oncol. 2015, 33, 2780-2788. [CrossRef] [PubMed]

62. Liu, B.L.; Robinson, M.; Han, Z.-Q.; Branston, R.H.; English, C.; Reay, P.; McGrath, Y.; Thomas, S.K.; Thornton, M.; Bullock, P.; et al. ICP34.5 deleted herpes simplex virus with enhanced oncolytic, immune stimulating, and anti-tumour properties. Gene Ther. 2003, 10, 292-303. [CrossRef]

63. Cheema, T.A.; Wakimoto, H.; Fecci, P.E.; Ning, J.; Kuroda, T.; Jeyaretna, D.S.; Martuza, R.L.; Rabkin, S.D. Multifaceted oncolytic virus therapy for glioblastoma in an immunocompetent cancer stem cell model. Proc. Natl. Acad. Sci. USA 2013, 110, 12006-12011. [CrossRef]

64. Bartlett, D.L.; Liu, Z.; Sathaiah, M.; Ravindranathan, R.; Guo, Z.; He, Y.; Guo, Z.S. Oncolytic viruses as therapeutic cancer vaccines. Mol. Cancer 2013, 12, 1-16. [CrossRef] [PubMed]

65. Kuryk, L.; Møller, A.-S.W.; Garofalo, M.; Cerullo, V.; Pesonen, S.; Alemany, R.; Jaderberg, M. Antitumor-specific T-cell responses induced by oncolytic adenovirus ONCOS-102 (AdV5/3-D24-GM-CSF) in peritoneal mesothelioma mouse model. J. Med. Virol. 2018, 90, 1669-1673. [CrossRef] [PubMed]

66. Kleijn, A.; Van den Bossche, W.; Haefner, E.S.; Belcaid, Z.; Burghoorn-Maas, C.; Kloezeman, J.J.; Pas, S.D.; Leenstra, S.; Debets, R.; De Vrij, J.; et al. The sequence of Delta24-RGD and TMZ administration in malignant glioma affects the role of CD8+T cell anti-tumor activity. Mol. Ther. Oncolytics 2017, 5, 11-19. [CrossRef]

67. Underhill, D.M.; Ozinsky, A. Phagocytosis of microbes: Complexity in action. Annu. Rev. Immunol. 2002, 20, 825-852. [CrossRef] [PubMed]

68. Iannacone, M.; Moseman, E.A.; Tonti, E.; Bosurgi, L.; Junt, T.; Henrickson, S.E.; Whelan, S.P.; Guidotti, L.G.; Von Andrian, U.H. Subcapsular sinus macrophages prevent CNS invasion on peripheral infection with a neurotropic virus. Nature 2010, 465, 1079-1083. [CrossRef]

69. Delwar, Z.M.; Kuo, Y.; Wen, Y.H.; Rennie, P.S.; Jia, W. Oncolytic virotherapy blockade by microglia and macrophages requires STAT1/3. Cancer Res. 2018, 78, 718-730. [CrossRef]

70. Kober, C.; Rohn, S.; Weibel, S.; Geissinger, U.; Chen, N.G.; Szalay, A.A. Microglia and astrocytes attenuate the replication of the oncolytic vaccinia virus LIVP 1.1.1 in murine GL261 gliomas by acting as vaccinia virus traps. J. Transl. Med. 2015, 13, 1-18. [CrossRef]

71. Alvarez-Breckenridge, C.; Kaur, B.; Chiocca, E.A. Pharmacologic and chemical adjuvants in tumor virotherapy. Chem. Rev. 2009, 109, 3125-3140. [CrossRef]

72. Kambara, H.; Saeki, Y.; Chiocca, E.A. Cyclophosphamide allows for in vivo dose reduction of a potent oncolytic virus. Cancer Res. 2005, 65, 11255-11258. [CrossRef]

73. Liu, Y.-P.; Suksanpaisan, L.; Steele, M.B.; Russell, S.J.; Peng, K.-W. Induction of antiviral genes by the tumor microenvironment confers resistance to virotherapy. Sci. Rep. 2013, 3, 1-9. [CrossRef]

74. Lamfers, M.L.M.; Fulci, G.; Gianni, D.; Tang, Y.; Kurozumi, K.; Kaur, B.; Moeniralm, S.; Saeki, Y.; Carette, J.E.; Weissleder, R.; et al. Cyclophosphamide increases transgene expression mediated by an oncolytic adenovirus in glioma-bearing mice monitored by bioluminescence imaging. Mol. Ther. 2006, 14, 779-788. [CrossRef]

75. Wakimoto, H.; Fulci, G.; Tyminski, E.; Chiocca, E.A. Altered expression of antiviral cytokine mRNAs associated with cyclophosphamide's enhancement of viral oncolysis. Gene Ther. 2004, 11, 214-223. [CrossRef] 
76. Fulci, G.; Breymann, L.; Gianni, D.; Kurozomi, K.; Rhee, S.S.; Yu, J.; Kaur, B.; Louis, D.N.; Weissleder, R.; Caligiuri, M.A.; et al. Cyclophosphamide enhances glioma virotherapy by inhibiting innate immune responses. Proc. Natl. Acad. Sci. USA 2006, 103, 12873-12878. [CrossRef]

77. Peng, K.-W.; Myers, R.; Greenslade, A.; Mader, E.; Greiner, S.; Federspiel, M.J.; Dispenzieri, A.; Russell, S.J. Using clinically approved cyclophosphamide regimens to control the humoral immune response to oncolytic viruses. Gene Ther. 2013, 20, 255-261. [CrossRef] [PubMed]

78. Ikeda, K.; Ichikawa, T.; Wakimoto, H.; Silver, J.S.; Deisboeck, T.S.; Finkelstein, D.; Harsh IV, G.R.; Louis, D.N.; Bartus, R.T.; Hochberg, F.H.; et al. Oncolytic virus therapy of multiple tumors in the brain requires suppression of innate and elicited antiviral responses. Nat. Med. 1999, 5, 881-887. [CrossRef]

79. Cerullo, V.; Diaconu, I.; Kangasniemi, L.; Rajecki, M.; Escutenaire, S.; Koski, A.; Romano, V.; Rouvinen, N.; Tuuminen, T.; Laasonen, L.; et al. Immunological Effects of Low-dose Cyclophosphamide in Cancer Patients Treated With Oncolytic Adenovirus. Mol. Ther. 2011, 19, 1737-1746. [CrossRef] [PubMed]

80. Zemp, F.J.; McKenzie, B.A.; Lun, X.; Reilly, K.M.; McFadden, G.; Yong, V.W.; Forsyth, P.A. Cellular factors promoting resistance to effective treatment of glioma with oncolytic Myxoma virus. Cancer Res. 2014, 74, 7260-7273. [CrossRef] [PubMed]

81. Ikeda, K.; Wakimoto, H.; Ichikawa, T.; Jhung, S.; Hochberg, F.H.; Louis, D.N.; Chiocca, E.A. Complement depletion facilitates the infection of multiple brain tumors by an intravascular, replication-conditional herpes simplex virus mutant. J. Virol. 2000, 74, 4765-4775. [CrossRef]

82. Han, J.; Chen, X.; Chu, J.; Xu, B.; Meisen, W.H.; Chen, L.; Zhang, L.; Zhang, J.; He, X.; Wang, Q.-E.; et al. TGF- $\beta$ treatment enhances glioblastoma virotherapy by inhibiting the innate immune response. Cancer Res. 2015, 75, 5273-5282. [CrossRef]

83. Shashkova, E.V.; Doronin, K.; Senac, J.S.; Barry, M.A. Macrophage depletion combined with anticoagulant therapy increases therapeutic window of systemic treatment with oncolytic adenovirus. Cancer Res. 2008, 68, 5896-5904. [CrossRef] [PubMed]

84. Buiting, A.M.J.; Zhou, F.; Bakker, J.A.J.; Van Rooijen, N.; Huang, L. Biodistribution of clodronate and liposomes used in the liposome mediated macrophage "suicide" approach. J. Immunol. Methods 1996, 192, 55-62. [CrossRef]

85. Fulci, G.; Dmitrieva, N.; Gianni, D.; Fontana, E.J.; Pan, X.; Lu, Y.; Kaufman, C.S.; Kaur, B.; Lawler, S.E.; Lee, R.J.; et al. Depletion of peripheral macrophages and brain microglia increases brain tumor titers of oncolytic viruses. Cancer Res. 2007, 67, 9398-9406. [CrossRef]

86. Lee, T.J.; Nair, M.; Banasavadi-Siddegowda, Y.; Liu, J.; Nallanagulagari, T.; Jaime-Ramirez, A.C.; Guo, J.Y.; Quadri, H.; Zhang, J.; Bockhorst, K.H.; et al. Enhancing Therapeutic Efficacy of Oncolytic Herpes Simplex Virus-1 with Integrin B1 Blocking Antibody OS2966. Mol. Cancer Ther. 2019, 18, 1127-1136. [CrossRef]

87. Mestas, J.; Hughes, C.C.W. Of mice and not men: Differences between mouse and human immunology. J. Immunol. 2004, 172, 2731-2738. [CrossRef]

88. Martinez, F.O.; Helming, L.; Gordon, S. Alternative activation of macrophages: An immunologic functional perspective. Annu. Rev. Immunol. 2009, 27, 451-483. [CrossRef]

89. Bracci, L.; Moschella, F.; Sestili, P.; La Sorsa, V.; Valentini, M.; Canini, I.; Baccarini, S.; Maccari, S.; Ramoni, C.; Belardelli, F.; et al. Cyclophosphamide enhances the antitumor efficacy of adoptively transferred immune cells through the induction of cytokine expression, B-cell and T-cell homeostatic proliferation, and specific tumor infiltration. Clin. Cancer Res. 2007, 13, 644-653. [CrossRef]

90. Sistigu, A.; Viaud, S.; Chaput, N.; Bracci, L.; Proietti, E.; Zitvogel, L. Immunomodulatory effects of cyclophosphamide and implementations for vaccine design. Semin. Immunopathol. 2011, 33, 369-383. [CrossRef] [PubMed]

91. Alvarez-Breckenridge, C.A.; Yu, J.; Price, R.; Wei, M.; Wang, Y.; Nowicki, M.O.; Ha, Y.P.; Bergin, S.; Hwang, C.; Fernandez, S.A.; et al. The histone deacetylase inhibitor valproic acid lessens NK cell action against oncolytic virus-infected glioblastoma cells by inhibition of STAT5/T-BET signaling and generation of gamma interferon. J. Virol. 2012, 86, 4566-4577. [CrossRef] [PubMed]

92. Ehrig, K.; Kilinc, M.O.; Chen, N.G.; Stritzker, J.; Buckel, L.; Zhang, Q.; Szalay, A.A. Growth inhibition of different human colorectal cancer xenografts after a single intravenous injection of oncolytic vaccinia virus GLV-1h68. J. Transl. Med. 2013, 11, 1-15. [CrossRef]

93. Kim, S.-I.; Park, A.K.; Chaurasiya, S.; Kang, S.; Lu, J.; Yang, A.; Sivanandam, V.; Zhang, Z.; Woo, Y.; Priceman, S.J.; et al. Recombinant Orthopoxvirus Primes Colon Cancer for Checkpoint Inhibitor and Cross-Primes T Cells for Antitumor and Antiviral Immunity. Mol. Cancer Ther. 2021, 20, 173-182. [CrossRef]

94. Parker, J.N.; Gillespie, G.Y.; Love, C.E.; Randall, S.; Whitley, R.J.; Markert, J.M. Engineered herpes simplex virus expressing IL-12 in the treatment of experimental murine brain tumors. Proc. Natl. Acad. Sci. USA 2000, 97, 2208-2213. [CrossRef]

95. Di Paolo, N.C.; Miao, E.A.; Iwakura, Y.; Murali-Krishna, K.; Aderem, A.; Flavell, R.A.; Papayannopoulou, T.; Shayakhmetov, D.M. Virus binding to a plasma membrane receptor triggers interleukin- $1 \alpha$-mediated proinflammatory macrophage response in vivo. Immunity 2009, 31, 110-121. [CrossRef] [PubMed]

96. Zsengellér, Z.; Otake, K.; Hossain, S.-A.; Berclaz, P.-Y.; Trapnell, B.C. Internalization of adenovirus by alveolar macrophages initiates early proinflammatory signaling during acute respiratory tract infection. J. Virol. 2000, 74, 9655-9667. [CrossRef]

97. Saha, D.; Martuza, R.L.; Rabkin, S.D. Macrophage polarization contributes to glioblastoma eradication by combination immunovirotherapy and immune checkpoint blockade. Cancer Cell 2017, 32, 253-267. [CrossRef] 
98. Morales-Molina, A.; Rodríguez-Milla, M.Á.; Gimenez-Sanchez, A.; Perisé-Barrios, A.J.; García-Castro, J. Cellular Virotherapy Increases Tumor-Infiltrating Lymphocytes (TIL) and Decreases their PD-1+ Subsets in Mouse Immunocompetent Models. Cancers 2020, 12, 1920. [CrossRef] [PubMed]

99. Geletneky, K.; Hajda, J.; Angelova, A.L.; Leuchs, B.; Capper, D.; Bartsch, A.J.; Neumann, J.O.; Schöning, T.; Hüsing, J.; Beelte, B.; et al. Oncolytic H-1 Parvovirus Shows Safety and Signs of Immunogenic Activity in a First Phase I/IIa Glioblastoma Trial. Mol. Ther. 2017, 25, 2620-2634. [CrossRef]

100. Van den Bossche, W.B.L.; Kleijn, A.; Teunissen, C.E.; Voerman, J.S.A.; Teodosio, C.; Noske, D.P.; Van Dongen, J.J.M.; Dirven, C.M.F.; Lamfers, M.L.M. Oncolytic virotherapy in glioblastoma patients induces a tumor macrophage phenotypic shift leading to an altered glioblastoma microenvironment. Neuro. Oncol. 2018, 1-31. [CrossRef]

101. Dijkgraaf, E.M.; Heusinkveld, M.; Tummers, B.; Vogelpoel, L.T.C.; Goedemans, R.; Jha, V.; Nortier, J.W.R.; Welters, M.J.P.; Kroep, J.R.; Van der Burg, S.H. Chemotherapy alters monocyte differentiation to favor generation of cancer-supporting M2 macrophages in the tumor microenvironment. Cancer Res. 2013, 73, 2480-2492. [CrossRef]

102. Gabrusiewicz, K.; Ellert-Miklaszewska, A.; Lipko, M.; Sielska, M.; Frankowska, M.; Kaminska, B. Characteristics of the alternative phenotype of microglia/macrophages and its modulation in experimental gliomas. PLoS ONE 2011, 6, e23902. [CrossRef] [PubMed]

103. Mehta, A.K.; Cheney, E.M.; Hartl, C.A.; Pantelidou, C.; Oliwa, M.; Castrillon, J.A.; Lin, J.-R.; Hurst, K.E.; De Oliveira Taveira, M.; Johnson, N.T.; et al. Targeting immunosuppressive macrophages overcomes PARP inhibitor resistance in BRCA1-associated triple-negative breast cancer. Nat. Cancer 2021, 2, 66-82. [CrossRef] [PubMed]

104. Wang, Q.; Lu, Y.; Li, R.; Jiang, Y.; Zheng, Y.; Qian, J.; Bi, E.; Zheng, C.; Hou, J.; Wang, S.; et al. Therapeutic effects of CSF1R-blocking antibodies in multiple myeloma. Leukemia 2018, 32, 176-183. [CrossRef] [PubMed]

105. Jakeman, P.G.; Hills, T.E.; Fisher, K.D.; Seymour, L.W. Macrophages and their interactions with oncolytic viruses. Curr. Opin. Pharmacol. 2015, 24, 23-29. [CrossRef]

106. Negishi, H.; Ohba, Y.; Yanai, H.; Takaoka, A.; Honma, K.; Yui, K.; Matsuyama, T.; Taniguchi, T.; Honda, K. Negative regulation of Toll-like-receptor signaling by IRF-4. Proc. Natl. Acad. Sci. USA 2005, 102, 15989-15994. [CrossRef]

107. Medzhitov, R.; Preston-Hurlburt, P.; Kopp, E.; Stadlen, A.; Chen, C.; Ghosh, S.; Janeway, C.A., Jr. MyD88 is an adaptor protein in the hToll/IL-1 receptor family signaling pathways. Mol. Cell 1998, 2, 253-258. [CrossRef]

108. Takaoka, A.; Yanai, H.; Kondo, S.; Duncan, G.; Negishi, H.; Mizutani, T.; Kano, S.; Honda, K.; Ohba, Y.; Mak, T.W.; et al. Integral role of IRF-5 in the gene induction programme activated by Toll-like receptors. Nature 2005, 434, 243-249. [CrossRef]

109. Kiyokawa, J.; Kawamura, Y.; Ghouse, S.M.; Acar, S.; Barçın, E.; Martínez-Quintanilla, J.; Martuza, R.L.; Alemany, R.; Rabkin, S.D.; Shah, K.; et al. Modification of Extracellular Matrix Enhances Oncolytic Adenovirus Immunotherapy in Glioblastoma. Clin. Cancer Res. 2021, 27, 889-902. [CrossRef]

110. Passaro, C.; Borriello, F.; Vastolo, V.; Di Somma, S.; Scamardella, E.; Gigantino, V.; Franco, R.; Marone, G.; Portella, G. The oncolytic virus d1922-947 reduces IL-8/CXCL8 and MCP-1/CCL2 expression and impairs angiogenesis and macrophage infiltration in anaplastic thyroid carcinoma. Oncotarget 2015, 7, 1500-1515. [CrossRef]

111. Kwan, A.; Winder, N.; Atkinson, E.; Al-Janabi, H.; Allen, R.J.; Hughes, R.; Moamin, M.; Louie, R.; Evans, D.; Hutchinson, M.; et al. Macrophages Mediate the Antitumor Effects of the Oncolytic Virus HSV1716 in Mammary Tumors. Mol. Cancer Ther. 2021, 20, 589-601. [CrossRef]

112. Liu, S.; Zhang, J.; Fang, S.; Zhang, Q.; Zhu, G.; Tian, Y.; Zhao, M.; Liu, F. Macrophage polarization contributes to the efficacy of an oncolytic HSV-1 targeting human uveal melanoma in a murine xenograft model. Exp. Eye Res. 2021, 202. [CrossRef] [PubMed]

113. Saha, D.; Martuza, R.L.; Rabkin, S.D. Oncolytic herpes simplex virus immunovirotherapy in combination with immune checkpoint blockade to treat glioblastoma. Immunotherapy 2018, 10, 779-786. [CrossRef] [PubMed]

114. Tan, D.Q.; Zhang, L.; Ohba, K.; Ye, M.; Ichiyama, K.; Yamamoto, N. Macrophage response to oncolytic paramyxoviruses potentiates virus-mediated tumor cell killing. Eur. J. Immunol. 2016, 46, 919-928. [CrossRef]

115. Angelova, A.L.; Barf, M.; Geletneky, K.; Unterberg, A.; Rommelaere, J. Immunotherapeutic potential of oncolytic H-1 parvovirus: Hints of glioblastoma microenvironment conversion towards immunogenicity. Viruses 2017, 9, 382. [CrossRef]

116. Accomando, W.P.; Rao, A.R.; Hogan, D.J.; Newman, A.M.; Nakao, A.; Alizadeh, A.A.; Diehn, M.; Diago, O.R.; Gammon, D.; Haghighi, A.; et al. Molecular and Immunologic Signatures are Related to Clinical Benefit from Treatment with Vocimagene Amiretrorepvec (Toca 511) and 5-Fluorocytosine (Toca FC) in Patients with Glioma. Clin. Cancer Res. 2020, 26, $6176-6186$. [CrossRef]

117. Zhang, J.-F.; Hu, C.; Geng, Y.; Selm, J.; Klein, S.B.; Orazi, A.; Taylor, M.W. Treatment of a human breast cancer xenograft with an adenovirus vector containing an interferon gene results in rapid regression due to viral oncolysis and gene therapy. Proc. Natl. Acad. Sci. USA 1996, 93, 4513-4518. [CrossRef]

118. Hu, Z.; Gerseny, H.; Zhang, Z.; Chen, Y.-J.; Berg, A.; Zhang, Z.; Stock, S.; Seth, P. Oncolytic adenovirus expressing soluble TGFbeta receptor II-Fc-mediated inhibition of established bone metastases: A safe and effective systemic therapeutic approach for breast cancer. Mol. Ther. 2011, 19, 1609-1618. [CrossRef]

119. Errington, F.; Steele, L.; Prestwich, R.; Harrington, K.J.; Pandha, H.S.; Vidal, L.; De Bono, J.; Selby, P.; Coffey, M.; Vile, R.; et al. Reovirus activates human dendritic cells to promote innate antitumor immunity. J. Immunol. 2008, 180, 6018-6026. [CrossRef]

120. Mercer, J.; Greber, U.F. Virus interactions with endocytic pathways in macrophages and dendritic cells. Trends Microbiol. 2013, 21, 380-388. [CrossRef] [PubMed] 
121. Asano, K.; Nabeyama, A.; Miyake, Y.; Qiu, C.-H.; Kurita, A.; Tomura, M.; Kanagawa, O.; Fujii, S.; Tanaka, M. CD169-positive macrophages dominate antitumor immunity by crosspresenting dead cell-associated antigens. Immunity 2011, 34, 85-95. [CrossRef]

122. Hickman, H.D.; Takeda, K.; Skon, C.N.; Murray, F.R.; Hensley, S.E.; Loomis, J.; Barber, G.N.; Bennink, J.R.; Yewdell, J.W. Direct priming of antiviral CD8+ T cells in the peripheral interfollicular region of lymph nodes. Nat. Immunol. 2008, 9, 155-165. [CrossRef]

123. Junt, T.; Moseman, E.A.; Iannacone, M.; Massberg, S.; Lang, P.A.; Boes, M.; Fink, K.; Henrickson, S.E.; Shayakhmetov, D.M.; Di Paolo, N.C.; et al. Subcapsular sinus macrophages in lymph nodes clear lymph-borne viruses and present them to antiviral B cells. Nature 2007, 450, 110-114. [CrossRef]

124. Jiang, H.; Clise-Dwyer, K.; Ruisaard, K.E.; Fan, X.; Tian, W.; Gumin, J.; Lamfers, M.L.; Kleijn, A.; Lang, F.F.; Yung, W.-K.A.; et al. Delta-24-RGD oncolytic adenovirus elicits anti-glioma immunity in an immunocompetent mouse model. PLoS ONE 2014, 9, e97407. [CrossRef] [PubMed]

125. Kaufman, H.L.; Kohlhapp, F.J.; Zloza, A. Oncolytic viruses: A new class of immunotherapy drugs. Nat. Rev. Drug Discov. 2015, 14, 642-662. [CrossRef]

126. Schietinger, A.; Philip, M.; Liu, R.B.; Schreiber, K.; Schreiber, H. Bystander killing of cancer requires the cooperation of CD4+ and CD8+ T cells during the effector phase. J. Exp. Med. 2010, 207, 2469-2477. [CrossRef]

127. Ino, Y.; Saeki, Y.; Fukuhara, H.; Todo, T. Triple combination of oncolytic herpes simplex virus-1 vectors armed with interleukin-12, interleukin-18, or soluble B7-1 results in enhanced antitumor efficacy. Clin. Cancer Res. 2006, 12, 643-652. [CrossRef] [PubMed]

128. Tseng, D.; Volkmer, J.-P.; Willingham, S.B.; Contreras-Trujillo, H.; Fathman, J.W.; Fernhoff, N.B.; Seita, J.; Inlay, M.A.; Weiskopf, K.; Miyanishi, M.; et al. Anti-CD47 antibody-mediated phagocytosis of cancer by macrophages primes an effective antitumor T-cell response. Proc. Natl. Acad. Sci. USA 2013, 110, 11103-11108. [CrossRef] [PubMed]

129. Cao, F.; Nguyen, P.; Hong, B.; DeRenzo, C.; Rainusso, N.C.; Rodriguez Cruz, T.; Wu, M.; Liu, H.; Song, X.; Suzuki, M.; et al. Engineering oncolytic vaccinia virus to redirect macrophages to tumor cells. Adv. Cell Gene Ther. 2021, 4, 1-13. [CrossRef]

130. Wirsching, H.-G.; Zhang, H.; Szulzewsky, F.; Arora, S.; Grandi, P.; Cimino, P.J.; Amankulor, N.; Campbell, J.S.; McFerrin, L.; Pattwell, S.S.; et al. Arming oHSV with ULBP3 drives abscopal immunity in lymphocyte-depleted glioblastoma. JCI Insight 2019, 4. [CrossRef] [PubMed]

131. Lawler, S.E.; Speranza, M.-C.; Cho, C.-F.; Chiocca, E.A. Oncolytic viruses in cancer treatment. JAMA Oncol. 2017, 3, 841-849. [CrossRef] [PubMed]

132. Russell, S.J.; Peng, K.W. Measles virus for cancer therapy. Curr. Top. Microbiol. Immunol. 2009, 330, 213-241. [CrossRef]

133. Biswas, M.; Johnson, J.B.; Kumar, S.R.P.; Parks, G.D.; Subbiah, E. Incorporation of host complement regulatory proteins into newcastle disease virus enhances complement evasion. J. Virol. 2012, 86, 12708-12716. [CrossRef] [PubMed]

134. Magge, D.; Guo, Z.S.; O’Malley, M.E.; Francis, L.; Ravindranathan, R.; Bartlett, D.L. Inhibitors of C5 complement enhance vaccinia virus oncolysis. Cancer Gene Ther. 2013, 20, 342-350. [CrossRef]

135. Mooney, R.; Majid, A.A.; Batalla-Covello, J.; Machado, D.; Liu, X.; Gonzaga, J.; Tirughana, R.; Hammad, M.; Lesniak, M.S.; Curiel, D.T.; et al. Enhanced Delivery of Oncolytic Adenovirus by Neural Stem Cells for Treatment of Metastatic Ovarian Cancer. Mol. Ther. Oncolytics 2019, 12, 79-92. [CrossRef]

136. Wang, Y.; Huang, H.; Zou, H.; Tian, X.; Hu, J.; Qiu, P.; Hu, H.; Yan, G. Liposome Encapsulation of Oncolytic Virus M1 to Reduce Immunogenicity and Immune Clearance in Vivo. Mol. Pharm. 2019, 16, 779-785. [CrossRef]

137. Dogrammatzis, C.; Waisner, H.; Kalamvoki, M. Cloaked Viruses and Viral Factors in Cutting Edge Exosome-Based Therapies. Front. Cell Dev. Biol. 2020, 8, 1-20. [CrossRef]

138. Coukos, G.; Makrigiannakis, A.; Kang, E.H.; Caparelli, D.; Benjamin, I.; Kaiser, L.R.; Rubin, S.C.; Albelda, S.M.; Molnar-Kimber, K.L. Use of carrier cells to deliver a replication-selective herpes simplex virus-1 mutant for the intraperitoneal therapy of epithelial ovarian cancer. Clin. Cancer Res. 1999, 5, 1523-1537.

139. Herrlinger, U.; Woiciechowski, C.; Sena-Esteves, M.; Aboody, K.S.; Jacobs, A.H.; Rainov, N.G.; Snyder, E.Y.; Breakefield, X.O. Neural precursor cells for delivery of replication-conditional HSV-1 vectors to intracerebral gliomas. Mol. Ther. 2000, 1, 347-357. [CrossRef] [PubMed]

140. Dey, M.; Yu, D.; Kanojia, D.; Li, G.; Sukhanova, M.; Spencer, D.A.; Pituch, K.C.; Zhang, L.; Han, Y.; Ahmed, A.U.; et al. Intranasal Oncolytic Virotherapy with CXCR4-Enhanced Stem Cells Extends Survival in Mouse Model of Glioma. Stem Cell Rep. 2016, 7, 471-482. [CrossRef]

141. Morshed, R.A.; Gutova, M.; Juliano, J.; Barish, M.E.; Hawkins-Daarud, A.; Oganesyan, D.; Vazgen, K.; Yang, T.; Annala, A.; Ahmed, A.U.; et al. Analysis of glioblastoma tumor coverage by oncolytic virus-loaded neural stem cells using MRI-based tracking and histological reconstruction. Cancer Gene Ther. 2015, 22, 55-61. [CrossRef]

142. Hammad, M.; Cornejo, Y.R.; Batalla-Covello, J.; Majid, A.A.; Burke, C.; Liu, Z.; Yuan, Y.-C.; Li, M.; Dellinger, T.H.; Lu, J.; et al. Neural Stem Cells Improve the Delivery of Oncolytic Chimeric Orthopoxvirus in a Metastatic Ovarian Cancer Model. Mol. Ther. Oncolytics 2020, 18, 326-334. [CrossRef] [PubMed]

143. Mader, E.K.; Maeyama, Y.; Lin, Y.; Butler, G.W.; Russell, H.M.; Galanis, E.; Russell, S.J.; Dietz, A.B.; Peng, K.-W. Mesenchymal stem cell carriers protect oncolytic measles viruses from antibody neutralization in an orthotopic ovarian cancer therapy model. Clin. Cancer Res. 2009, 15, 7246-7255. [CrossRef] [PubMed] 
144. Lamfers, M.; Idema, S.; Van Milligen, F.; Schouten, T.; Van der Valk, P.; Vandertop, P.; Dirven, C.; Noske, D. Homing properties of adipose-derived stem cells to intracerebral glioma and the effects of adenovirus infection. Cancer Lett. 2009, 274, 78-87. [CrossRef] [PubMed]

145. Yong, R.L.; Shinojima, N.; Fueyo, J.; Gumin, J.; Vecil, G.G.; Marini, F.C.; Bogler, O.; Andreeff, M.; Lang, F.F. Human Bone Marrow-Derived Mesenchymal Stem Cells for Intravascular Delivery of Oncolytic Adenovirus Delta-24-RGD to Human Gliomas. Cancer Res. 2009, 69, 8932-8940. [CrossRef]

146. Du, W.; Seah, I.; Bougazzoul, O.; Choi, G.; Meeth, K.; Bosenberg, M.W.; Wakimoto, H.; Fisher, D.; Shah, K. Stem cell-released oncolytic herpes simplex virus has therapeutic efficacy in brain metastatic melanomas. Proc. Natl. Acad. Sci. USA 2017, 114, E6157-E6165. [CrossRef] [PubMed]

147. Adair, R.A.; Scott, K.J.; Fraser, S.; Errington-Mais, F.; Pandha, H.; Coffey, M.; Selby, P.; Cook, G.P.; Vile, R.; Harrington, K.J.; et al. Cytotoxic and immune-mediated killing of human colorectal cancer by reovirus-loaded blood and liver mononuclear cells. Int. J. Cancer 2013, 132, 2327-2338. [CrossRef] [PubMed]

148. Jennings, V.A.; Ilett, E.J.; Scott, K.J.; West, E.J.; Vile, R.; Pandha, H.; Harrington, K.; Young, A.; Hall, G.D.; Coffey, M.; et al Lymphokine-activated killer and dendritic cell carriage enhances oncolytic reovirus therapy for ovarian cancer by overcoming antibody neutralization in ascites. Int. J. Cancer 2014, 134, 1091-1101. [CrossRef] [PubMed]

149. Ilett, E.; Kottke, T.; Donnelly, O.; Thompson, J.; Willmon, C.; Diaz, R.; Zaidi, S.; Coffey, M.; Selby, P.; Harrington, K.; et al. Cytokine conditioning enhances systemic delivery and therapy of an oncolytic virus. Mol. Ther. 2014, 22, 1851-1863. [CrossRef]

150. Balvers, R.K.; Belcaid, Z.; Van den Hengel, S.K.; Kloezeman, J.; De Vrij, J.; Wakimoto, H.; Hoeben, R.C.; Debets, R.; Leenstra, S.; Dirven, C.; et al. Locally-delivered T-cell-derived cellular vehicles efficiently track and deliver adenovirus Delta24-RGD to infiltrating glioma. Viruses 2014, 6, 3080-3096. [CrossRef] [PubMed]

151. Roulstone, V.; Khan, K.; Pandha, H.S.; Rudman, S.; Coffey, M.; Gill, G.M.; Melcher, A.A.; Vile, R.; Harrington, K.J.; De Bono, J.; et al. Phase I trial of cyclophosphamide as an immune modulator for optimizing oncolytic reovirus delivery to solid tumors. Clin. Cancer Res. 2015, 21, 1305-1312. [CrossRef] [PubMed]

152. Burke, S.; Shergold, A.; Elder, M.J.; Whitworth, J.; Cheng, X.; Jin, H.; Wilkinson, R.W.; Harper, J.; Carroll, D.K. Oncolytic Newcastle disease virus activation of the innate immune response and priming of antitumor adaptive responses in vitro. Cancer Immunol. Immunother. 2020, 69, 1015-1027. [CrossRef]

153. Muthana, M.; Giannoudis, A.; Scott, S.D.; Fang, H.-Y.; Coffelt, S.B.; Morrow, F.J.; Murdoch, C.; Burton, J.; Cross, N.; Burke, B.; et al. Use of macrophages to target therapeutic adenovirus to human prostate tumors. Cancer Res. 2011, 71, 1805-1815. [CrossRef]

154. Muthana, M.; Rodrigues, S.; Chen, Y.-Y.; Welford, A.; Hughes, R.; Tazzyman, S.; Essand, M.; Morrow, F.; Lewis, C.E. Macrophage delivery of an oncolytic virus abolishes tumor regrowth and metastasis after chemotherapy or irradiation. Cancer Res. 2013, 73, 490-495. [CrossRef]

155. Berkeley, R.A.; Steele, L.P.; Mulder, A.A.; Van den Wollenberg, D.J.M.; Kottke, T.J.; Thompson, J.; Coffey, M.; Hoeben, R.C.; Vile, R.G.; Melcher, A.; et al. Antibody-Neutralized Reovirus Is Effective in Oncolytic Virotherapy. Cancer Immunol. Res. 2018, 6, 1161-1173. [CrossRef]

156. Willmon, C.; Harrington, K.; Kottke, T.; Prestwich, R.; Melcher, A.; Vile, R. Cell carriers for oncolytic viruses: Fed ex for cancer therapy. Mol. Ther. 2009, 17, 1667-1676. [CrossRef] [PubMed]

157. Rider, P.; Carmi, Y.; Guttman, O.; Braiman, A.; Cohen, I.; Voronov, E.; White, M.R.; Dinarello, C.A.; Apte, R.N. IL-1a and IL-1b recruit different myeloid cells and promote different stages of sterile inflammation. J. Immunol. 2011, 187, 4835-4843. [CrossRef]

158. Van den Bossche, W.B.L.; Vincent, A.J.P.E.; Teodosio, C.; Koets, J.; Taha, A.; Kleijn, A.; De Bruin, S.; Dik, W.A.; Damasceno, D.; Almeida, J.; et al. Monocytes carrying GFAP detect glioma, brain metastasis and ischaemic stroke, and predict glioblastoma survival. Brain Commun. 2020, 3, 1-12. [CrossRef]

159. Qiao, J.; Wang, H.; Kottke, T.; White, C.; Twigger, K.; Diaz, R.M.; Thompson, J.; Selby, P.; De Bono, J.; Melcher, A.; et al. Cyclophosphamide facilitates antitumor efficacy against subcutaneous tumors following intravenous delivery of reovirus. Clin. Cancer Res. 2008, 14, 259-269. [CrossRef] [PubMed]

160. Ferguson, M.S.; Chard Dunmall, L.S.; Gangeswaran, R.; Marelli, G.; Tysome, J.R.; Burns, E.; Whitehead, M.A.; Aksoy, E.; Alusi, G.; Hiley, C.; et al. Transient Inhibition of PI3K $\delta$ Enhances the Therapeutic Effect of Intravenous Delivery of Oncolytic Vaccinia Virus. Mol. Ther. 2020, 28, 1263-1275. [CrossRef]

161. Yoo, J.Y.; Swanner, J.; Otani, Y.; Nair, M.; Park, F.; Banasavadi-Siddegowda, Y.; Liu, J.; Jaime-Ramirez, A.C.; Hong, B.; Geng, F.; et al. Oncolytic HSV therapy increases trametinib access to brain tumors and sensitizes them in vivo. Neuro. Oncol. 2019, 21, 1131-1140. [CrossRef] [PubMed]

162. Chiocca, E.A. A Study of the Treatment of Recurrent Malignant Glioma With rQNestin34.5v.2 (rQNestin). Available online: https: / / clinicaltrials.gov / ct2 / show / NCT03152318?term=chiocca\&draw=2\&rank=1 (accessed on 26 July 2021).

163. Eftimie, R.; Eftimie, G. Investigating Macrophages Plasticity Following Tumour-Immune Interactions During Oncolytic Therapies. Acta Biotheor. 2019, 67, 321-359. [CrossRef] [PubMed] 